\title{
Achieving Bologna Convergence: Is ECTS failing to make the grade?
}

\section{TERENCE KARRAN,}

[This is an electronic version of an article published in Higher Education in Europe, Vol. 29, No. 3, October 2004. Higher Education in Europe is available online at: http://www.informaworld.com]

ABSTRACT: Transparent and consistent credit transfer procedures are essential if EU Universities are to successfully build the European Higher Education Learning Area and thrive in the emerging global knowledge economy. Currently the European Credit Transfer System is the most widely used mechanism to enable credit transfer between universities in different EU nations. Using data from 20 universities in four EU states, this paper examines the problems of calculating and using ECTS grades. The results demonstrate that the alignment of ECTS grades varies within nation states and show that, despite the fact that ECTS grading is a norm referenced system, while the national systems are usually criterion referenced, many ECTS conversion tables provided by universities indicate straight line transference from institutional to ECTS grades. Given the anticipated increase in student mobility following the EU enlargement to 25 nations, the paper proposes a re-alignment of ECTS towards a criterion referenced system. Such a new system would acknowledge and build on the diversity of EU higher education systems, unlike the current mechanistic system, which both masks this diversity and is flawed in calculation, and ad hoc in operation.

\section{Introduction}

The process of the convergence of European higher education systems began at the Sorbonne on May 25th 1998 when the Education Ministers from France, Germany, Italy and the United Kingdom signed a Joint Declaration On Harmonisation Of The Architecture Of The European Higher Education System committing their nations to "encouraging a common frame of reference, ... (to) ... create a European area of higher education.”(Allegre et al. 1998). The four signatories successfully called on other European Union (EU) Member States, and other European countries, to join them in this objective, with the result that the Bologna Declaration was signed on 19th June 1999 by the national government Ministers in charge of higher education of 29 European nations, including all the (then) members of the EU. 
A major driver of the process of convergence of the EU higher education systems has been the European Credit Transfer System (ECTS), which led the Ministers who produced the Berlin Communiqué in September 2003 to "stress the important role played by the European Credit Transfer System (ECTS) in facilitating student mobility and international curriculum development. (and) ... note that ECTS is increasingly becoming a generalised basis for the national credit systems”(2003, p. 4). Research undertaken by Reichert and Tauch (2003) for the European University Association confirmed "a high degree of acceptance and momentum for this once controversial tool has been reached almost all over Europe ... ECTS has spread fast all over Europe and has been included in many higher education laws” (p.66). However, they also reported that "ECTS as a tool is undergoing rapid and far-reaching extensions before it has been properly understood in its original form in many institutions. ... the system is still applied in a very rudimentary or haphazard fashion to student exchange and credit transfer"(p.66).

This paper examines the application of the ECTS grading system, and its different use by individual universities, within national systems of assessment. In order to determine the policy context for this analysis, and the importance of credit issues, the paper initially outlines the central role of credit and assessment within the emerging global market for higher education, before examining the use of ECTS as a mechanism for facilitating credit transfer through national case studies. The implications of these findings are then considered within an assessment of the requirements of a grading system for European higher education.

\section{Credit and Credit Transfer in the global H.E. market}

Credits for qualifications are the currency of the emerging borderless higher education market place, and credit transfer systems like ECTS define the rate of exchange. The ability of universities to deal with credit and assessment issues will affect their success within the global knowledge economy and the information society. If universities do not offer units with widely accepted credit values, they will be unable to attract students from both home and overseas markets, who will not enter programmes if the resultant qualifications have limited recognition elsewhere, with other universities and employers. In essence, universities need to develop a "global currency for higher education qualifications" (Randall, 2002) because if their programs don't provide credits that are recognised, they will be denied access to the new global educational market at a time, the OECD (2000) has calculated, of "rapid growth in the number of students enrolled educational institutions outside their home country”(p. 91). Conversely, universities that cannot recognise the credits of other institutions will be unable 
to recruit students, especially post-graduates, both from other institutions providing accredited academic qualifications and also from professional associations and organisations that certificate vocational practice and experience. Furthermore, incoming academic staff will judge the credibility of a recruiting university in terms of the value attributed to its qualifications by students, by other universities, and the distribution of its alumni within elite universities and multi-national companies. In addition, the encroachment of market forces in education and the adoption of consumerist attitudes by students, many of whom study while working and pay tuition fees themselves, necessitates assessment procedures and protocols that are sufficiently well-grounded and professional in execution to address both institutional audit by the growing number of national and supra-national quality agencies (e.g. the European Network for Quality Assurance in Higher Education), and the growing possibility of litigation action by dissatisfied students. At a strategic level, the inability of universities to align their credit systems to others will limit the possibility of building critical mass in the global borderless education market by collaboration, not only with other universities, but with other major knowledge-centred corporate players.

If credits are viewed as the currency within the new global borderless education market, then assessment and grading procedures can be considered as the die-stamping presses through which students process subject content to create this coinage. However, even if courses provided by two different universities have identical subject content and are worth the same value in respect of credits, their entire rationale may be different by virtue of different assessment modes and grading procedures. Moreover, within Europe, different national educational systems utilise widely varying assessment procedures, marking systems, and grading schemes, and within each of those national systems there is institutional variance in how national procedures are interpreted and used. As Guy Haug (1997) has remarked "Grading systems differ in philosophy and practice from one country to another, and the fair interpretation of foreign grades into national ones is a major issue, both for students returning after a study period abroad and for university staff required to assess the credentials of foreign applicants.”

\section{The European Credit Transfer System}

Within the EU, the well-known Erasmus (European Action Scheme for the Mobility of University Students) program has become, as de Wit (1996) notes "the key motor for internationalisation of higher education in the European Union ... complemented by similar programs on a global scale: the TEMPUS program for cooperation with Central and Eastern 
Europe”(p.6). Maiworm and Teichler (1997) have confirmed the evident success of the scheme - the number of Erasmus students exceeded one million students by October 2002, leading the (then) European Commissioner for Education and Culture, Vivienne Reding (2003a), to "urge the Ministers to join forces with public and private sponsors in order to triple the number of Erasmus students by 2010.” Involvement in programmes such as Erasmus by European Universities, has promoted greater use of credit transfer between institutions and across different educational systems. The extension of support funding via the new Erasmus Mundus programme will permit even greater student mobility, by encouraging the inflow of students from outside the EU.

The European Credit Transfer System (ECTS) was developed by the European Commission to enable the recognition of study periods abroad, funded under the Erasmus and similar programmes, and comprises three constituent elements:

a An information pack/course catalogue for incoming students from outside the nation of the host institution which includes:

a A learning agreement specifying the courses to be taken, and agreed by the student and his home university and the host university;

a A transcript of records detailing the students performance in the courses taken, calculated in the local grading system and ECTS grades.

The marking schemes utilised within the higher education systems of the EU vary considerably and ECTS is designed to act as a "grade converter", enabling students to transport the grade outcomes of their studies quickly and easily across national boundaries. The ECTS grades a student is granted for courses undertaken at a foreign university are determined by use of the ECTS Grade Definition table, given below.

Table 1 ECTS Grade Definitions

\begin{tabular}{|c|c|l|}
\hline $\begin{array}{c}\text { ECTS } \\
\text { Grade }\end{array}$ & $\begin{array}{c}\text { \% of students } \\
\text { achieving the grade }\end{array}$ & \multicolumn{1}{c|}{ Definition } \\
\hline A & 10 & Excellent - outstanding performance with only minor errors \\
\hline B & 25 & Very Good - above the average standard but with some errors \\
\hline C & 30 & Good - generally sound work but with a number of notable errors \\
\hline D & 25 & Satisfactory - fair but with significant shortcomings \\
\hline E & 10 & Sufficient - performance meets the minimum criteria \\
\hline FX & & Fail - some more work required before the credit can be awarded \\
\hline F & & Fail - considerable further work is required \\
\hline
\end{tabular}

Source: http://europa.eu.int/comm/education/programmes/socrates/ects_en.html

The ECTS uses norm-referencing for the calculation of grades. All students successfully passing the evaluation or examination are listed from that with the highest mark to that with the lowest. Then, within the list, the precise grade points for the five different 
ECTS percentile groups from ' $A$ ' to ' $E$ ' are established and lines drawn to indicate the dividing points between:

' $\mathrm{A}$ ' = the top ten percentile;

' $\mathrm{B}$ ' = the next twenty five percentile;

' $\mathrm{C}$ ' = the next thirty percentile;

' $D$ ' = the next twenty five percentile;

' $\mathrm{E}$ ' = the remaining ten percentile.

By 2003 Reichert and Tauch found that two thirds of HEIs use ECTS for credit transfer but observed "The basic elements and principles of ECTS seem simple enough, but its implementation in the highly differentiated European higher education systems is fraught with all sorts of problems” (p.70). It is to some of those problems that we now turn.

\section{Problems in Calculating ECTS}

The wide spread use of ECTS seemingly attests to its simplicity in calculating grades and its ease of use. However, problems can occur in calculating ECTS grades. First, ECTS grades are only calculated for those students who pass the unit, and the differences in the setting of pass marks means that that the percentage of students who fail an evaluation/examination can vary from one country/institution/faculty/department/subject area to another. Hence in one nation the ECTS will be calculated on the basis of the $60 \%$ of students on a course who achieve a pass, while the same students taking a similar course in another country may find that the ECTS grades are calculated only for $40 \%$, as the pass mark in the second university is higher. Secondly, in order to calculate students ECTS accurately, it is necessary to use historical data from the same course, to get sufficient information to ensure that the mark distribution is an accurate reflection of spread of marks for the course. The amount of historical data needed will vary depending on the number of students taking the course, but typically, data over a four year period will be needed for accurate norm referencing. It is then possible to identify the ECTS grading boundaries and award the correct grades. However, this approach has limited utility in the first few years of a new course, when it is also more likely that student numbers taking the unit will be low. Moreover using this method means that the student's performance is not being measured against the current cohort of students but historically against all previous students. This can clearly create unfair anomalies as the course content will vary over time, as knowledge within the particular subject area develops, while changes in staff turnover may mean that the course is both delivered and assessed differently, from one year to the next. In addition the requirement of each university to retain 
and update a data base covering students results for a four year period makes the system both bureaucratically burdensome and time consuming.

A further problem with ECTS calculation is that some European higher education assessment systems have very few grade points. For example within the Spanish system successful students are awarded one of six grades from 5-10 on a grading scale of 0-10, with five as the pass grade. Similarly in Finland the grades go from 1 (Välttävä = Sufficient) to 3 (Erinomaiset Tiedot $=$ Excellent), with intermediate grades used in some institutions, but not all. Hence using these national grading scales results in very large students groups, which cannot be easily mapped on to the ECTS system. Introducing intermediate grade points within the national system for the assessment of foreign students units can overcome this problem, although staff may find it difficult to assign intermediate grades that are in contravention of national schemes and academic customs. This problem is heightened when the national grading scheme is descriptive and non-numeric, as in the case of Sweden where students are allocated three non numeric grades: Rest (Conditional Pass), Godkänd (Pass), or Väl Godkänd, (Pass with distinction). In such circumstances it becomes necessary to use a qualitative approach and attempt to match the verbal descriptions used within the ECTS grading system against the national grading descriptors. Although this can be done, it is an imperfect process, given that that terms used for ECTS grades ('excellent', 'very good', 'good', 'satisfactory', 'sufficient') have different national, cultural and academic nuances, and can be interpreted in very different ways, across Europe, given that as Yorke (2001) has noted "Much practice in the area of grading appears to be based on tradition, with whatever thinking that originally underpinned this having been become lost in the mists of time.” (p. 61)

\section{Problems in Using ECTS}

The grading mechanisms of some national h.e. systems can make the calculation of ECTS difficult, but the majority utilise numeric systems, and are sufficiently comprehensive to allow ECTS grades to be calculated. However, further more serious problems occur with the use, rather than the calculation, of the ECTS grading system. First, the vast majority of grading systems used in higher education in EU nation states are criterion referenced and hence attempt to determine a student's grade by comparing his or her achievements with implicit or explicit stated standards for particular levels of performance. Hence it is possible that all students on a course could receive very high (or very low) grades depending on the levels of individuals' performance against the established criteria. However even if all students on a course passed with very low grades via criterion referenced marking, $10 \%$ of them would, 
nevertheless, be allocated an ECTS Grade 'A', through its norm referenced system. Conversely, as norm referencing means that a student's grade depends not only on his or her level of achievement, but also on the achievement of others, a student may obtain a high grade via criterion referenced marking, but still be only given an ECTS Grade ' $\mathrm{C}$ ', as his/her peers also obtained high grades via criterion referenced marking.

Secondly, difficulties arise when trying to fairly and consistently interpret ECTS grades awarded in other institutions, as it is up to the receiving institution as to how it interprets an ECTS grade awarded to a student by another university. Hence a student obtaining the grade of 30 e lode for a course offered by an Italian University would probably be given an ECTS 'A' grade, while students awarded 29 and 30 would be given a grade 'B'. Hence translating ECTS grade into (say) a British equivalent is difficult as Italian Universities designate circa $14 \%$ of all grades at 30 e lode, while in the U.K. typically only $8 \%$ of students are awarded first-class honours, moreover there is huge subject variation within the grading system of the U.K. Hence for example, Yorke et al. (2002) found that 22\% of U.K. first degree awards in Mathematics were at first class honours level, while the comparable figure for first class honours in Law degree awards was only 4.1\%. Moreover Chapman (1997) reported "significant differences in degree class distributions for the same subject between one university and another"(p.151). Similarly, raw data gathered by the author from one Italian University indicated that (as in the U.K.) there are subject differences in the mark spreads within Italian Universities. It is likely that in other nations there are variations between subjects in the proportions of different grades awarded, but these variations will be different in different nations. In another country, for example, it may be the case that $10 \%$ of Law students get the highest grade, while the comparable figure for Mathematics is less than $5 \%$.

Thirdly, and most critically, custom and practice have tended to move the perception (and use) of ECTS away from norm to criterion referencing. For example, the detailed ECTS Guidance Notes provided for Latvian Universities (now seeking to participate in European Higher Education Area) by the national Academic Program Agency (n.d.) state:

It is quite possible that, once the percentile groups represented by the ECTS grades from 'A' to ' $E$ ' have been established, one or more of them may be found to equate very closely to such groups established by the local grading scale. This coincidence may be close enough for it to be possible to award, year-on-year, the ECTS grades according to groups created by the local grading scale. ... Where near total correspondence has proved possible between a local grading scale and 
the ECTS grading scale, some institutions have been able to print 'straight-line' conversion tables from their local grades into ECTS grades. ... institutions which discover clear and direct lines of comparison with ECTS grades are greatly encouraged to exploit this coincidence. (p. 4f)

Similarly the English ECTS Guidance notes issued by the Europa Website (n.d.) state: "in assigning an ECTS grade 'A', a British institution awarding first-class honours to 8\% of its students may well decide to retain the same definition of 'Excellence' for the ETCS Grade.” Such strategies, where adopted, represent a corruption of the norm referenced rationale behind ECTS, and moreover could disadvantage students. More fundamentally, it is difficult to endorse a grading scheme in which the student's award may ultimately depend on the successful exploitation of coincidence.

Students' understanding of the mechanisms of assessment and grading are critical given that, as Brown (2001) observed "assessment defines what students regard as important, how they spend their time and how they come to see themselves as students and graduates" (p. 4). Hence a student taking an ECTS graded unit will ask the local tutor how much effort will be needed for a pass and an ECTS 'A' grade. Successful exploitation of the happy coincidence between the norm referenced ECTS and institutional and national criterion referenced grading systems is apparently widespread, making it simple to advise incoming students how much effort is required to gain the different norm referenced ECTS grades, and how these relate to the internal institutional and national grading systems, which are usually criterion referenced.

However, case study evidence gathered from 20 European Universities, as part of an EU Socrates Minerva project, points to huge variation in the ways in which institutional/national grades are related to ECTS grades. Despite the fact that ECTS grading is a norm referenced system, while the national systems are usually criterion referenced, ECTS conversion tables provided by universities indicate straight line transference from institutional to ECTS grades, and the use of such tables is not confined to a particular nation, but general across the European Union. Moreover, in addition to wrongly ascribing norm referenced ECTS grades to national criterion referenced grades, there appears to be little national (or institutional) consistency as to how this procedure is undertaken as the tables below demonstrate. It is possible that such inconsistencies may relate to subject differences, although more usually ECTS conversion tables are supplied on an institutional rather than a subject basis. 
Table 2 Use of ECTS in France

\begin{tabular}{|c|c|c|c|c|c|}
\hline $\begin{array}{l}\text { ECTS } \\
\text { Grade }\end{array}$ & $\begin{array}{c}\text { University } 1 \\
\text { Grade Description }\end{array}$ & $\begin{array}{c}\text { University } 2 \\
\text { Grade Description }\end{array}$ & $\begin{array}{c}\text { University } 3 \\
\text { Grade Description }\end{array}$ & $\begin{array}{c}\text { University } 4 \\
\text { Grade Description }\end{array}$ & $\begin{array}{c}\text { University } 5 \\
\text { Grade Description }\end{array}$ \\
\hline A & $\begin{array}{l}16-20 \\
\text { Très Bien }\end{array}$ & $\begin{array}{c}18-20 \\
\text { Excellent }\end{array}$ & $\begin{array}{c}>\text { or }=14.5 \text { Très } \\
\text { Bien \& Bien }\end{array}$ & $\begin{array}{l}16 \text { ou plus } \\
\text { Excellent }\end{array}$ & $\begin{array}{c}>15 \\
\text { Excellent }\end{array}$ \\
\hline B & $\begin{array}{c}14-16 \\
\text { Bien }\end{array}$ & $\begin{array}{c}\text { 16-18 } \\
\text { Très Bien }\end{array}$ & $\begin{array}{l}\text { > or }=13 \text { Bien } \\
\text { \& Assez Bien }\end{array}$ & $\begin{array}{c}14 \\
\text { Très Bien }\end{array}$ & $\begin{array}{c}15-12 \\
\text { Très Bien }\end{array}$ \\
\hline $\mathrm{C}$ & $\begin{array}{c}12-14 \\
\text { Assez Bien }\end{array}$ & $\begin{array}{c}14-16 \\
\text { Bien }\end{array}$ & $\begin{array}{l}>\text { or }=11.7 \\
\text { Assez Bien }\end{array}$ & $\begin{array}{c}12 \\
\text { Bien }\end{array}$ & $\begin{array}{l}12-10 \\
\text { Bien }\end{array}$ \\
\hline D & $\begin{array}{c}10-12 \\
\text { Passable }\end{array}$ & 12-14 Satisfaisant & $\begin{array}{l}>\text { or }=11 \\
\text { Passable }\end{array}$ & $\begin{array}{c}11 \\
\text { Satisfaisant }\end{array}$ & $\begin{array}{c}10-8 \\
\text { Satisfaisant }\end{array}$ \\
\hline $\mathrm{E}$ & & 08-12 Passable & $\begin{array}{l}>\text { or }=10 \\
\text { Passable }\end{array}$ & $\begin{array}{c}10 \\
\text { Passable }\end{array}$ & $\begin{array}{c}\text { 8-6 } \\
\text { Passable }\end{array}$ \\
\hline FX & $\begin{array}{c}\text { Inférieur à } 10 \\
\text { Echec }\end{array}$ & 00-08 Insuffisant & $\begin{array}{l}<10 \\
\text { Echec }\end{array}$ & $\begin{array}{c}8 \text { ou } 9 \\
\text { Insuffisant } \\
\end{array}$ & $\begin{array}{c}<6 \\
\text { Insuffisant }\end{array}$ \\
\hline $\mathrm{F}$ & & & $\begin{array}{c}<6 \text { Echec } \\
\text { probant }\end{array}$ & $\begin{array}{c}7 \text { ou moins } \\
\text { Echec }\end{array}$ & \\
\hline
\end{tabular}

Sources: http://www.ensm-douai.fr/fr/gbversion/studying.html http://www.ema.fr/infos_international/ECTS-03-04/2003-ects-info.html http://www.icmo.u-psud.fr/w-erasmus/ae_depgene.htm http://www.psycho.univ-paris5.fr/html/NKMS34DWQXPXPZ2H.shtml http://www.ensc-lille.fr/int_fr/ECTS/echelle.html

As can be seen from table 2 above, Universities 2 and 5 in France would award the ECTS Grade ' $E$ if a student achieved 8 out of 20 in an examination, while the other three would not. At the other end of the scale, University 3 would award an ECTS grade ' $A$ ' if the student achieved a grade of 14.5 out of 20, while University 2 requires between 18 and 20 to get the 'A' Grade. Across the table, there is no single ECTS grade for which all five institutions are in agreement. This lack of uniformity is as marked in Greece, as table 3 shows below. Three of the five Greek Universities in the table award the national grade descriptor of 'Excellent' to students scoring above 8.5 out of 10, and make no discrimination between ECTS grades ' $A$ ' and ' $B$ '. At the lower end of the scale there is some unanimity about what constitutes a fail, but three institutions truncate ECTS Grades 'FX' and 'F'.

Table 3 Use of ECTS in Greece

\begin{tabular}{|c|c|c|c|c|c|}
\hline $\begin{array}{l}\text { ECTS } \\
\text { grade }\end{array}$ & $\begin{array}{c}\text { University } 1 \\
\text { Grade Description }\end{array}$ & $\begin{array}{c}\text { University } 2 \\
\text { Grade Description }\end{array}$ & $\begin{array}{c}\text { University } 3 \\
\text { Grade Description } \\
\end{array}$ & $\begin{array}{c}\text { University } 4 \\
\text { Grade Description }\end{array}$ & $\begin{array}{c}\text { University } 5 \\
\text { Grade Description } \\
\end{array}$ \\
\hline A & $\begin{array}{l}9.0 \text { to } 10: \\
\text { Excellent }\end{array}$ & $\begin{array}{l}8.5 \text { to } 10 \\
\text { Excellent }\end{array}$ & \multirow{2}{*}{$\begin{array}{l}\text { Excellent } \\
8.50-10\end{array}$} & \multirow{2}{*}{$\begin{array}{l}\text { Excellent } \\
8.50-10\end{array}$} & $\begin{array}{c}\text { Excellent } \\
10\end{array}$ \\
\hline B & $\begin{array}{c}8 \text { to } 8.5: \\
\text { Very Good }\end{array}$ & $\begin{array}{c}7 \text { to } 8.4 \\
\text { Very Good }\end{array}$ & & & $\begin{array}{l}\text { Very Good } \\
8,9\end{array}$ \\
\hline $\mathrm{C}$ & $\begin{array}{l}7 \text { to } 7.5: \\
\text { Good }\end{array}$ & $\begin{array}{c}6 \text { to } 6.9 \\
\text { Good }\end{array}$ & $\begin{array}{l}\text { Very Good } \\
7.0-8.4\end{array}$ & $\begin{array}{l}\text { Very Good } \\
6.5-8.49\end{array}$ & $\begin{array}{c}\text { Good } \\
7\end{array}$ \\
\hline $\mathrm{D}$ & $\begin{array}{c}6 \text { to } 6.5: \\
\text { Satisfactory }\end{array}$ & $\begin{array}{c}5.1 \text { to } 5.9 \\
\text { Satisfactory }\end{array}$ & $\begin{array}{c}\text { Good } \\
5.1-6.9\end{array}$ & $\begin{array}{c}\text { Good } \\
5.01-6.49\end{array}$ & $\begin{array}{c}\text { Almost Good } \\
6\end{array}$ \\
\hline $\mathrm{E}$ & $\begin{array}{l}5 \text { to 5.9: } \\
\text { Sufficient }\end{array}$ & $\begin{array}{c}5 \text { Lowest } \\
\text { Passing Grade }\end{array}$ & $\begin{array}{l}\text { Passing Grade } \\
5\end{array}$ & $\begin{array}{l}\text { Passing Grade } \\
5\end{array}$ & 5 Passing Grade \\
\hline FX & $\begin{array}{c}4 \text { to } 4.5 \\
\text { Fail }\end{array}$ & $\begin{array}{c}4 \text { to } 4.9 \\
\text { Insufficient }\end{array}$ & \multirow{2}{*}{$\begin{array}{c}\text { Fail } \\
0-4.9\end{array}$} & \multirow{2}{*}{$\begin{array}{c}\text { Fail } \\
0-4.49\end{array}$} & \multirow[t]{2}{*}{ Fail } \\
\hline $\mathrm{F}$ & $\begin{array}{l}0 \text { to } 3.5 \\
\text { Fail }\end{array}$ & $\begin{array}{c}0 \text { to } 3.9 \\
\text { Fail }\end{array}$ & & & \\
\hline
\end{tabular}


Sources: http://www.tuc.gr/english/erasmus/pem.doc http://www.teipat.gr/pages/civil/dept_e.htm http://www.nutr.teithe.gr/engcourseofstudy.htm http:// www.csd.auth.gr/download/ects_en.doc http://www.med.auth.gr/school/eng/depart.htm

The assignment of norm referenced ECTS Grades to national criterion referenced grades appears more uniform in Italy (see Table 4 below), as 30 or 30 e lode usually corresponds with the ECTS Grade 'A', while a mark of 18 or more is sufficient to pass. However there is considerable variation in the calculation of intermediate grades. For a student scoring 23, University 1 would grant an ECTS Grade 'E', while Universities 2, 4 and 5 would grant the ECTS Grade 'D'. Similarly Universities 1, 3, and 5 would award an ECTS Grade ' $C$ ' if a student achieved 27 out of 30, while Universities 'B' and 'D' would award an ECTS Grade 'B’.

Table 4 Use of ECTS in Italy

\begin{tabular}{|c|c|c|c|c|c|}
\hline $\begin{array}{l}\text { ECTS } \\
\text { grade }\end{array}$ & $\begin{array}{c}\text { University } 1 \\
\text { Grade Description }\end{array}$ & $\begin{array}{c}\text { University } 2 \\
\text { Grade Description }\end{array}$ & $\begin{array}{c}\text { University } 3 \\
\text { Grade Description }\end{array}$ & $\begin{array}{c}\text { University } 4 \\
\text { Grade Description }\end{array}$ & $\begin{array}{c}\text { University } 5 \\
\text { Grade Description }\end{array}$ \\
\hline A & $\begin{array}{l}\text { 30-30 Lode: } \\
\text { Excellent }\end{array}$ & $\begin{array}{l}\text { 30-30 Lode: } \\
\text { Excellente }\end{array}$ & $\begin{array}{l}30 \text { e lode } \\
\text { Excellente }\end{array}$ & $\begin{array}{l}\text { 28-30 Cum } \\
\text { Laude }\end{array}$ & 30-30 e lode \\
\hline B & $\begin{array}{c}28-29 \\
\text { Very Good }\end{array}$ & $\begin{array}{c}27-29 \\
\text { Molto Buono }\end{array}$ & $\begin{array}{c}30 \\
\text { Molto Buono }\end{array}$ & $26-27$ & $28-29$ \\
\hline $\mathrm{C}$ & 26-27: Good & $\begin{array}{l}\text { 24-26: } \\
\text { Buono }\end{array}$ & $\begin{array}{l}27-29 \\
\text { Buono: }\end{array}$ & $24-25$ & 25-27: \\
\hline $\mathrm{D}$ & $\begin{array}{c}24-25: \\
\text { Satisfactory }\end{array}$ & $\begin{array}{c}\text { 19-23: } \\
\text { Soddisfacente }\end{array}$ & $\begin{array}{c}25-26 \\
\text { Soddisfacente }\end{array}$ & $22-23$ & $20-24$ \\
\hline $\mathrm{E}$ & 18-23: Sufficient & 18: Sufficiente & 18-24 Sufficiente & $18-21$ & $18-19$ \\
\hline FX & & $14-17$ & Insufficiente & \multirow{2}{*}{$0-18$} & \\
\hline $\mathrm{F}$ & & $0-13$ & & & \\
\hline
\end{tabular}

Sources: http://www.unipv.it/webbio/socrates/ectscale.htm http:// http://nicosia.dia.uniroma3.it/Erasmus/scale.html http://www.lumsa.it/info/relazioni_internaz.html http:// http://utenti.lycos.it/ects/ http:// http://web.unicam.it/studenti/socrates/ects.htm

The situation in the Netherlands is similarly random. As Table 5 shows the mark required to secure an ECTS Pass Grade ' $E$ ' is 5.5 in two universities and 6 in two others, with the last university requiring a grade of 5.8 to pass, but making no distinction between Grades ' $D$ ' and ' $E$ '. Examining the highest grade 'A', Universities 4 and 5 require 9.5 out of 10 for ECTS Grade 'A', Universities 1 and 2 require 9, but University 3 only requires 8.3 out of 10 a score which, if achieved in Universities 4 and 5, would only result in a Grade 'C'. 
Table 5 Use of ECTS in Netherlands

\begin{tabular}{|c|c|c|c|c|c|}
\hline $\begin{array}{l}\text { ECTS } \\
\text { grade }\end{array}$ & $\begin{array}{c}\text { University } 1 \\
\text { Grade Description }\end{array}$ & $\begin{array}{c}\text { University } 2 \\
\text { Grade Description }\end{array}$ & $\begin{array}{c}\text { University } 3 \\
\text { Grade Description }\end{array}$ & $\begin{array}{c}\text { University } 4 \\
\text { Grade Description }\end{array}$ & $\begin{array}{c}\text { University } 5 \\
\text { Grade Description }\end{array}$ \\
\hline A & 9-10: Excellent & $9-10$ & $8.3-10$ & above 9.5 & $9.5-10$ \\
\hline B & $\begin{array}{c}\text { 8.5: } \\
\text { Very Good }\end{array}$ & $8-9$ & $7.3-8.2$ & $\begin{array}{c}\text { between } 8.5 \\
\text { and } 9.49 \\
\end{array}$ & $8.5-9.4$ \\
\hline $\mathrm{C}$ & 8 - 7.5: Good & $7-8$ & $6.3-7.2$ & $\begin{array}{c}\text { between } 7.5 \\
\text { and } 8.49 \\
\end{array}$ & $7.6-8.4$ \\
\hline $\mathrm{D}$ & $\begin{array}{c}7 \text { - 6.5: } \\
\text { Satisfactory }\end{array}$ & $6-7$ & \multirow{2}{*}{$5.8-6.2$} & $\begin{array}{c}\text { between } 6.5 \\
\text { and } 7.49 \\
\end{array}$ & $6.6-7.5$ \\
\hline $\mathrm{E}$ & $\begin{array}{c}6, \\
\text { Sufficient }\end{array}$ & 6 & & $\begin{array}{c}\text { between } 5.5 \\
\text { and } 6.49\end{array}$ & $5.5-6.5$ \\
\hline FX & \multirow[t]{2}{*}{$1,2,3,4,5$} & 5 & $5.0-5.7$ & $\begin{array}{l}\text { between } 4.5 \\
\text { and } 5.49\end{array}$ & $0-5.4$ \\
\hline $\mathrm{F}$ & & $1-4$ & $0.0-4.9$ & less than 4.49 & \\
\hline
\end{tabular}

Sources: http://odur.let.rug.nl/internationaloffice/ects.pdf http://www.el.utwente.nl/onderwijs/edu_r.shtml http://www.tilburguniversity.nl/students/studying/ects/scale.html http://www.mhpe.unimaas.nl/docs/mhpe\%20examrules\%202003.doc http://site.educatie.han.nl/cie//

Table 6 summarises the variety in the institutions' grading systems and their use of ECTS, and demonstrates how the choice of university could be crucial in determining students' grades. Most students using the possibility of Erasmus funding opt to study at one other university, but for this example the hypothetical assumption has been made that two students are studying for units at universities in France, Greece, Italy and the Netherlands. Both students have been awarded the same above average grades via the national marking system scoring 15/20 in the French University, 7.4/10 in the Greece University, 28/30 in the Italian University and 7.3/10 in the University in the Netherlands. However, one student has studied at University 3 in France, University 2 in Greece, University 4 in Italy and University 3 in the Netherlands - this lucky choice and the exploitation of the happy coincidence between ECTS and national grades has enabled the students to achieve two ECTS Grade 'A's, and two Grade 'B's. By contrast the other student has unluckily chosen to study at University 2 in France, University 1 in Greece, University 3 in Italy and University 5 in the Netherlands, and although achieving the same marks as his lucky counterpart is only able to achieve three ECTS Grade 'C’s and one Grade ' $D$ '.

Table 6 Summary Table- Best and Worst Scenarios

\begin{tabular}{|c|c|c|c|c|}
\hline Nation and Local Score & $\begin{array}{c}\text { France } \\
15 / 20\end{array}$ & $\begin{array}{c}\text { Greece } \\
7.4 / 10\end{array}$ & $\begin{array}{c}\text { Italy } \\
28 / 30\end{array}$ & $\begin{array}{c}\text { Netherlands } \\
7.3 / 10\end{array}$ \\
\hline University 1: ECTS Grade & $\mathrm{B}$ & $\mathrm{C}$ & $\mathrm{B}$ & $\mathrm{D}$ \\
\hline University 2: ECTS Grade & $\mathrm{C}$ & $\mathrm{B}$ & $\mathrm{B}$ & $\mathrm{C}$ \\
\hline University 3: ECTS Grade & $\mathrm{A}$ & $\mathrm{C}$ & $\mathrm{C}$ & $\mathrm{B}$ \\
\hline University 4: ECTS Grade & $\mathrm{B}$ & $\mathrm{C}$ & $\mathrm{A}$ & $\mathrm{D}$ \\
\hline University 5: ECTS Grade & $\mathrm{B}$ & $\mathrm{B}$ & $\mathrm{B}$ & $\mathrm{D}$ \\
\hline Lucky Student & $\mathrm{A}$ & $\mathrm{B}$ & $\mathrm{A}$ & $\mathrm{B}$ \\
\hline Unlucky Student & $\mathrm{C}$ & $\mathrm{C}$ & $\mathrm{C}$ & $\mathrm{D}$ \\
\hline
\end{tabular}




\section{Conclusions and Recommendations}

A macro level analysis of ECTS by Adams (2001a) for the European Commission found that "The current state of the SOCRATES/ERASMUS ECTS is relatively healthy and buoyant. It is accepted and used by over one thousand higher education institutions. The tools it uses are tried and tested and have been shown to be effective. The principles on which it is based are sound" (p. 19). The increased use of ECTS has lead Adams (2001b) to assert that "ECTS is being transformed from an important but peripheral activity to something at the heart of national and institutional education. ECTS is now moving centre-stage as a device to meld erstwhile incompatible educational systems and practices” (p. 36). By contrast, Sullivan's (2002) more recent micro level institutional study of ECTS based on anecdotal evidence from an exchange between a Swedish and UK university concluded that "neither is ECTS grade transfer the simple matter that university literature promoting SOCRATES purports, nor does the transferred grade reflect a similar level of achievement to that which the home university claims to assume” (p. 73). This analysis verifies this study and endorses Van Damme's (2001) criticism of ECTS that "In its pragmatic and voluntaristic approach and with its reliance on a great deal of optimistic (some would say 'naive') trust and confidence, it has chosen to bypass questions of content comparability, educational culture and, of crucial importance, quality" (p. 435). Similarly, Haug (1997) believes that "foreign grades are not just numbers that can be calculated by applying a mathematical formula, but a message that needs first to be understood in the original system and in a second stage interpreted by users in their own system. Simple mathematical formulas with their claim to universality are nothing but a fallacious oversimplification of a reality they fail to capture." As well as revealing problems with the application of ECTS grades, the tables above also expose institutional variation in the use of national grading systems. This variation is neither conducive to accurate international credit transfer, nor suggestive of robust national quality assurance procedures that safeguard students' interests by applying national grading standards consistently, both within institutions and between subject departments.

The increase in the number of European Union nation states in May 2004 from 15 to 25, all with their own cultural norms and nationally distinct systems of grading and assessment, provides an apposite moment to appraise the existing institutional usage of the ECTS, to check that it is operating fairly and equitably and in the interest of students, before attempting to extend its use to the new members of the EU. Currently ECTS: 
\ calculates grades on different sizes of student cohorts depending on where the pass mark is set by the university running the course - where the pass mark for a unit is $50 \%$ and habitually only $70 \%$ of students achieve a pass grade, it is likely that the ECTS Grading will be applied to a smaller student cohort than if the pass mark is set at $40 \%$ and $80 \%$ of students are anticipated to pass;

口 uses a norm based referencing system and thereby calculates students' grades in accordance with the performance of their peers, rather than via a criterion referencing system which judges the student's ability to achieve the learning outcomes of courses;

a may wrongly penalise or reward students, depending on whether there have been changes to the course delivery and assessment over the period from which data is collected;

\ has national coherence in some EU nations, and is applied accurately, but is wrongly applied as if it were a criterion referenced system in others, and even then, applied differently by individual institutions.

Any assessment and grading system utilised across the EU must address the needs of a hierarchy of stakeholders and potentials users, including students (seeking credits for academic advancement), teaching staff (assessing the impact of their efforts), universities (ensuring national and institutional quality standards are met), employers (trying to recruit qualified staff), governments (pursuing national policy objectives), and the EU (trying to create the European H.E. Area). Currently it is debatable whether ECTS is meeting the diverse needs of these (and other) stakeholders. At the very least any grading system adopted at European level must be able to:

\ apply uniform pass/fail benchmarks to enable progression;

口 enable identification of excellence, permitting entry to higher degrees;

\ allow students to accurately monitor their learning progress;

a monitor the impact of teaching;

a provide a differentiated ranking of grades to reflect a range of different abilities against agreed standards of knowledge and competence;

ـ encourage students to strive for excellence - all grades must be achievable;

a enable retrieval of failure without loss of recognition for the grade;

口 be universally applicable across a range of disciplines and nations, in an easy, transparent, and equitable fashion.

At present ECTS does not meet these requirements. Largely because, as Adams (2001c) admits, “The main problems are that ECTS is not always consistently applied, nor is it always 
properly understood” (p.297). More critically however, within its adoption there is a move being encouraged to equate ECTS norm referenced grades with national criterion referenced grades, in a manner which is ad hoc and unsystematic. Moreover the wide spread use and very simplicity of the ECTS has given it a highly misleading "veneer of validity, reliable and standard maintenance” (Sullivan, 2002, p.73).

To enable EU universities to compete in the global borderless educational market, the ECTS should be as coherent and robust as that used in other major trading blocs. Before ECTS is installed as the norm in the accession states, work should be undertaken to re-align ECTS from a norm to a criterion referenced system. This would involve applying new parameters to the ECTS categories, in terms of scores within the national grading systems, such that (for example) a student scoring 27-29 for a unit studied at an Italian University would always be awarded an ECTS grade 'B', irrespective as to the grades obtained by his current or previous fellow students. Such a re-calibration of ECTS grades would have a direct symmetry with, and would strengthen, the shift towards defining ECTS credits in terms of achieving learning outcomes rather than study hours taken. Indeed, there is little point in utilising learning outcomes within credit definitions unless they are used with a criterion referenced marking scheme which assesses the extent to which the outcomes are achieved by students. Work undertake by Morrison et al. (1997) indicates that it would be possible to create "A Europe-wide uniform mark scale (which) would ensure that all universities could quickly appraise the academic profile of a visiting student by glancing at his or her achievements to date, calibrated in uniform marks” (p.412). In addition, the current mechanistic mode of calculating ECTS, masks rather than celebrates the strengths and diversity of national h.e. systems, and does not encourage academic staff to understand the rationale and benefits of marking schemes in other nation states. A further benefit of such an appraisal would be to increase the consistency of national assessment and grading systems within the universities of individual EU nations.

The highly complex but successful creation of the Euro as a common currency in January 2002, replacing the many different national currencies that then existed, and enabling a free flow of goods and services across the European area, shows that such reforms, although radical, are both feasible and beneficial. Similarly, to maximize the returns of the emerging European knowledge economy, knowledge, in the form of credits, must be easily portable between states and across borders. The mobility of knowledge would benefit greatly from having a common currency of standard academic grades and thereby portable qualifications, enabling free flow for the knowledge of its citizens with consequent rises in student and 
labour mobility. In her address at the Berlin Bologna meeting in September 2003, Viviane Reding (2003b) told the Higher Education Ministers that "Quality Assurance ... is really at the heart of the Bologna process and deserves its prominent place in our draft Communiqué.” and stated that she was "looking at ways in which the Commission can help greater consistency in the use of ECTS.” This study suggests that if quality assurance procedures in credit transference between EU nation states are to operate properly and fairly, the ECTS grading process will need to move to a criterion referenced system, while both national and ECTS grading procedures will need to be applied with much greater consistency at both institutional and national levels, if they are to retain the credibility of the academic staff and students who use them.

\section{REFERENCES}

ADAM, S., (2001a) Report For The European Commission: ECTS Extension Feasibility Project accessed from http://europa.eu.int/comm/education/programmes/socrates/ectsrap.pdf on 10 June 2004.

ADAM, S., (2001b) Credit Recognition And Transparency In Transnational Education, European Journal of Legal Education, Vol.1, p. 35- 42.

ADAM, S., (2001c) A Pan-European Credit Accumulation Framework - Dream or Disaster?, Higher Education Quarterly, 55(3), pp. 293-305.

ALLEGRE, C., BERLINGUER, L., BLACKSTONE, T., RÜTTGERS, J., (1998) Sorbonne Joint Declaration On Harmonisation Of The Architecture Of The European Higher Education System, Paris, the Sorbonne, May 251998.

BROWN, G., (2001), “Assessment: A Guide for Lecturers”, LTSN Generic Centre Assessment Series No. 3, (York: LTSN).

CHAPMAN, K., (1997), "Degrees of Difference: Variability of Degree Results in UK Universities”, Higher Education, 33 (?), p.137-153.

CONFERENCE OF EU HIGHER EDUCATION MINISTERS, (2003) Communiqué: Realising the European Higher Education Area.

DE WIT, H., (1996), European Internationalization Programs, International Higher Education, 4, p.5-6.

EUROPEAN COMMISSION, (2004) European Credit Transfer System: ECTS Users' Guide, accessed from http://europa.eu.int/comm/education/programmes/socrates/ects/guide_en.pdf on 10th August 2004. 
HAUG, G., (1997) Capturing the Message Conveyed by Grades: Interpreting Foreign Grades, World Education News and Reviews, 10, 2.

LATVIAN ACADEMIC PROGRAM AGENCY, (n.d.) The ECTS Grading Scale, accessed from http://www.apa.lv/Socrates/Erasmus/ECTS/ECTSGRADINGSCALE.doc on 10th June 2004.

MAIWORM, F., TEICHLER, U., (1997), The Erasmus Experience, Major Findings of the ERASMUS Evaluation Research Project, (Luxembourg: Office for Official Publications of the European Communities).

MORRISON, H., COWAN, P., HARTE, S., (1997), The Impact of Modular Aggregation on the Reliability of Final Degrees and the Transparency of European Credit Transfer, Assessment and evaluation in Higher Education, 22(4), pp. 405- 417.

O.E.C.D., (2002) “The Growth of Cross-Border Education”, Education Policy Analysis, (O.E.C.D., Paris), p.89-116.

RANDALL, J. (2001) Defining Standards: Developing a Global Currency For Higher Education Qualifications, INQAAHE 2001 Conference Proceedings, p.46-56.

REDING, V., (2003a) Making European Higher Education a Worldwide Reference, Keynote Address, EUA Convention of European Higher Education Institutions, Graz, 29th May 2003. REDING, V., (2003b) We need to implement wholeheartedly the Bologna process, Keynote Address, Berlin conference on Higher Education, Berlin, 18 September 2003.

REICHERT, S., TAUC, C., (2003) Trends 2003: Progress towards the European H.E. Area, (EUA: Brussels).

SULLIVAN, K., (2002), “Credit and grade transfer within the European Union’s SOCRATES programme: unity in diversity or head in the sand?”, Assessment and Evaluation in Higher Education, 27(1), pp. 65-74.

VAN DAMME, D., (2001) “Quality issues in the internationalisation of higher education”, Higher Education, 41(4), pp. 415-441.

YORKE, M., (2001) “Assessment: A Guide for Senior Managers”, LTSN Generic Centre Assessment Series No. 1, (York: LTSN).

YORKE, M., BARNETT, G., BRIDGES, P., EVANSON, P., HAINES, C., JENKINS, D., KNIGHT, P., SCURRY, D., STOWELL, M., WOOLF, H., (2002) “Does Grading Method Influence Honours Degree Classification?”, Assessment and Evaluation in Higher Education, 27(3), pp.269 - 279. 